\title{
SEROPREVALENCE OF HEPATITIS B SURFACE ANTIGEN AMONG SOUTH-WESTERN NIGERIAN UNDERGRADUATES
}

\section{JEMILOHUN A.C. ${ }^{*}$, OYELADE B.0. ${ }^{2}$ AND OIWOH S.0. ${ }^{3}$}

1Department of Medicine, Gastroenterology Unit, Ladoke Akintola University of Technology Teaching Hospital, P.M.B. 4007, Ogbomoso, Oyo State 210214, Nigeria.

2Ladoke Akintola University of Technology Health Center, Ogbomoso, Oyo State 210214, Nigeria.

3Department of Medicine, Ladoke Akintola University of Technology Teaching Hospital, Ogbomoso, Oyo State 210214, Nigeria.

*Corresponding Author: Email- chrislohun2010@hotmail.com

Received: July 04, 2013; Accepted: July 16, 2013

\begin{abstract}
This study was carried out to determine the seroprevalence of Hepatitis B surface antigen (HBsAg) among south-western Nigerian undergraduates, a basically healthy young adult population, who are the main potential blood donors in the society. The investigators obtained permission from the management of the Ladoke Akintola University of Tehcnology (LAUTECH) Health Center, Ogbomoso to access the medical records of the first-year university students who underwent routine post-admission medical screening exercise. The demographic information of students and the hepatitis B virus status were copied. Their personal identification information such as names and admission numbers were not copied to ensure anonymity. A total of 1,572 students with a mean age of $19.61( \pm 2.75)$ years were included in the study. The age range was $15-50$ years. Of the 1,572 subjects, $821(52.2 \%)$ were males while $751(47.8 \%)$ were females. Majority of the subjects (99.6\%) were aged $15-30$ years. Those aged $\geq 31$ years were comparatively few $(0.6 \%)$. Of the 1,572 students, 77 tested positive, giving a general Hepatitis B Virus (HBV) carriage of $4.9 \%$ in the population tested. Of the 821 male students, $54(6.6 \%)$ tested positive while 23 (3.1\%) of the 751 female subjects were positive. Age group 31-40 years had the highest prevalence HBsAg (20\%). Age-groups $\leq 20,21-30$ and $\geq 41$ years had $4.8 \%, 5 \%$ and nil respectively. Hepatitis B Virus has a moderate prevalence among the south-western adult population of Nigeria as against the national prevalence which is generally believed to be high.
\end{abstract}

Keywords- Hepatitis, Virus, Antigen, Prevalence, Infection, Nigeria

Citation: Jemilohun A.C., Oyelade B.O. and Oiwoh S.O. (2013) Seroprevalence of Hepatitis B Surface Antigen among South-Western Nigerian Undergraduates. International Journal of Microbiology Research, ISSN: 0975-5276 \& E-ISSN: 0975-9174, Volume 5, Issue 4, pp.-445-447.

Copyright: Copyright@2013 Jemilohun A.C., et al. This is an open-access article distributed under the terms of the Creative Commons Attribution License, which permits unrestricted use, distribution and reproduction in any medium, provided the original author and source are credited.

\section{Introduction}

Hepatitis B virus (HBV) infection is a global health challenge because it is a major cause of serious liver diseases (chronic hepatitis, liver cirrhosis and hepatocellular carcinoma) worldwide [1]. An estimate of two billion people is infected globally with HBV, of which 350 million suffer from chronic infection. Between 500000 to 1.2 million deaths per annum occur as a result the chronic sequelae of the infection [2]. Although, chronic hepatitis is relatively uncommon and mainly acquired in adulthood in the western countries of the world, it is endemic in the developing countries of Asia and Africa and often acquired perinatally or in childhood [2]. Hepatitis B virus is highly contagious; the virus is $50-100$ times more infectious than the human immunodeficiency virus (HIV) [3]. It is very resilient and does survive outside the body for a considerable time.

It is easily transmitted through contact with infected blood and body fluids [2]. The virus is essentially transmitted by two broad modes of transmission, i.e. vertical transmission from mother to child during the perinatal period and in infancy; and horizontally through use of unsterilized sharp objects, unsafe injections, unprotected sexual intercourse, and unsafe blood and blood products transfusion practices, especially in the developing world [2,4].

The prevalence of HBV varies from one region of the globe to another. Prevalence is classified into low $(<2 \%)$, intermediate $(2-7 \%)$ and high (>8\%) [1]. Nigeria belongs to the group of countries with high prevalence and has an estimated exposure rate of about $75 \%$ $[2,4,5]$. About $12 \%$ of Nigerians are estimated as chronic carriers, though prevalence rates among population groups in the country vary [6].

Factors associated with transmission of blood borne infections through contaminated blood and blood products are quite common in Nigeria. These include lack of centralized blood transfusion system, lack of enforcement of regulations guiding blood transfusion, indiscriminate blood transfusion practices, and dominance of commercial donors among blood donors [7]. Hence, the high incidence of health conditions requiring blood transfusion in Nigeria, such as road traffic accidents, pregnancy-related bleeding, armed robbery attacks, and violent events, will all contribute to an increase in the probability of the transmission of HBV and other blood-borne infec- 
tions through contaminated blood [8].

In the light of the foregoing, this study aims to determine the seroprevalence of HBsAg among south-western Nigerian undergraduates of the Ladoke Akintola University of Technology, Ogbomoso, a basically young adult population, who are the major potential blood donors in the society.

\section{Materials and methods}

\section{Study population}

Subjects consisted of students of the Ladoke Akintola University of Technology (LAUTECH), Ogbomoso undergoing routine postadmission medical screening for the admission year 2012. The LAUTECH, Ogbomoso student population consists majorly of male and female young adults from the south-western region of Nigeria and a minority from other regions of the country.

\section{Data Collection}

The investigators obtained permission from the management of the Ladoke Akintola University of Technology (LAUTECH) Health Center, Ogbomoso to access the medical records of the first-year university students who underwent routine post-admission medical screening exercise. The demographic information of students and the hepatitis B virus status were copied. Their personal identification information such as names and admission numbers was not copied to ensure anonymity.

\section{Sample Processing}

All tests were done using rapid HBsAg test kit manufactured by Health-chem diagnostics, USA. The kit consists of a chromatographic absorbent membrane strip immobilized with unique polyclonal specific antibodies with a high sensitivity. The antigen in the sample reacts with a colored conjugate of a monoclonal specific to $\mathrm{HBsAg}$. An antigen-antibody complex is formed when antigen is present in the sample. The mixture then moves upward and the immuno-complex labeled with dye will be captured by the polyclonal antibody immobilized on the membrane, producing a red color band. The test has a $99.4 \%$ correlation with ELISA test. The test device has a built-in control to minimize error. External control is also done with known serum pool to ascertain accuracy and detect batch to batch variation. Procedure was performed according to the manufacturer's instruction.

\section{Statistical Analysis}

Data were analyzed by SPSS 16. Differences between proportions were evaluated by chi-square test, using contingency tables. Statistical significance was achieved if is $\leq 0.05$.

\section{Results}

A total of 1572 students with a mean age of $19.61( \pm 2.75)$ years were included in the study. Of these, $821(52.2 \%)$ were males while 751 (47.8\%) were females. Majority of the subjects (99.6\%) were aged $15-30$ years. Those aged $\geq 31$ years were comparatively few $(0.6 \%)$ [Table-1].

Of the 1572 students, 77 were reactive to the test, giving a general HBV carriage of $4.9 \%$ in the population tested. Of the 821 male students, $54(6.6 \%)$ tested positive while $23(3.1 \%)$ of the $751 \mathrm{fe}$ male subjects were positive [Table-2]. This gender related prevalence was statistically significant.

[Table-3] shows the age related prevalence of the subjects. Age group 31-40 years had the highest prevalence HBsAg (20\%). Age- groups $\leq 20,21-30$ and $\geq 41$ years had $4.8 \%, 5 \%$ and nil respectively. The observed differences were not however statistically significant.

Table 1- Age and Gender distribution of subjects

\begin{tabular}{|lccc|}
\hline \multicolumn{3}{c}{ Gender } & Total (\%) \\
\hline $15-20$ & Male (\%) & Female (\%) & $1164(74.0)$ \\
$21-30$ & $549(34.9)$ & $615(39)$. & $398(25.3)$ \\
$31-40$ & $262(16.7)$ & $136(8.7)$ & $5(0.3)$ \\
$41-50$ & $5(0.3)$ & $0(0)$ & $5(0.3)$ \\
Total & $5(0.3)$ & $0(0)$ & $1572(100)$ \\
\hline
\end{tabular}

Mean=19.61, $S D= \pm 2.75$

Table 2- Prevalence of HBV with respect to Gender

\begin{tabular}{|lccc|}
\hline \multirow{2}{*}{ Gender } & \multicolumn{2}{c|}{ HBV status } & Total (\%) \\
\hline Male & Positive (\%) & Negative (\%) & \\
Female & $54(6.6)$ & $767(93.4)$ & $821(100)$ \\
Total & $23(3.1)$ & $728(96.9)$ & $751(100)$ \\
\hline & $77(4.9)$ & $1495(95.1)$ & $1,572(100)$ \\
\hline
\end{tabular}

$X^{2}=10.401 ; d f=1 ; P=0.001$

Table 3-Prevalence of HBV with respect to Age

\begin{tabular}{|lccc|}
\hline \multicolumn{4}{c}{ HBV status } \\
Age & Positive $(\%)$ & Negative $(\%)$ & Total \\
\hline$\leq 20$ & $56(4.8)$ & $1,108(95.2)$ & $1,164(100)$ \\
$21-30$ & $20(5.0)$ & $378(95.0)$ & $398(100)$ \\
$31-40$ & $1(20)$ & $4(80)$ & $5(100)$ \\
$\geq 41$ & $0(0.0)$ & $5(100)$ & $5(100)$ \\
Total & $77(4.9)$ & $1495(95.1)$ & $1572(100)$ \\
\hline
\end{tabular}

$X^{2}=3.005 ; d f=3 ; P=0.426$

\section{Discussion}

The world regional prevalence of HBV is classified into low $(<2 \%)$, intermediate $(2-7 \%)$ and high (>8\%) [1]. Nigeria is said to belong to the high prevalence region of the world $[2,4]$.

The finding of a prevalence of $4.9 \%$ in this study indicates a moderate prevalence of HBV among the young adult population of the south-western region of Nigeria. Since the student population of LAUTECH, Ogbomoso consists mainly of young adults from all over the south-western region of Nigeria; this result is expected to mirror closely the overall prevalence of HBsAg in the general adult population in the region. This result is similar to a $2.1 \%$ prevalence obtained in a study in Port-Harcourt among University students and $3.8 \%$ among pregnant women in Abuja [9, 10]. However, higher values of $11.5 \%$ was found among University students of Keffi, Nasarawa State, 14.3 and 20\% among blood donors in Jos and Benue respectively, and $18.2 \%$ among pregnant women in Zaria $[3,6,8,11]$.

The observed variation in the prevalence of HBV in this study and those conducted in other parts of the country cannot be easily explained. However, this may be as a result of the disparity in the sample sizes used in the studies. It may also be a reflection of the regional variation in the prevalence of $\mathrm{HBV}$ in the country.

Gender related viral prevalence analysis reveals that the male subjects had higher carriage rate than the females $(3.4 \%$ vs $1.5 \%)$, and this difference was found to be statistically significant $(P=0.001)$. $A$ similar observation, though not statistically significant, was reported 
in previous studies from Keffi, Nasarawa State and Jos, Plateau State of Nigeria $[3,8]$. This Higher male prevalence may not be unconnected to higher rate of sexual promiscuity among males than females which had been reported for Nigeria [3].

In this study, higher HBsAg seroprevalence rate (20\%) was observed among the 31-40 years age category of subjects, while the infection was totally absent amongst those aged $\geq 41$ years (Table 3). Notwithstanding that this peak prevalence of infection is similar to that reported by some studies conducted in the southern parts of Nigeria; it may not be a true reflection of the prevalence of HBV in this age-group as only 5 of such subjects were involved in our study $[9,12]$. It is also important to note that the dearth of participants in some of the age-groups may have altered the overall picture of the age related prevalence of HBV infection in this study.

\section{Conclusion}

We conclude that HBV has a moderate prevalence among the south-western adult population of Nigeria as against the national prevalence which is generally believed to be high. This study has provided additional data on the burden of HBV infection in Nigeria. Since previous HBV prevalence studies conducted in Nigeria were usually limited to sub-populations, a comprehensive national survey of the prevalence of HBV with the aim of determining the national prevalence, regional prevalence variation and the peculiar associated risk factors for acquiring the disease is desirable. This will help in formulating the strategic action plan necessary to reducing the burden of the disease in the country at large.

\section{Conflict of Interest}

The authors declare no competing interest.

\section{Author's Contributions}

A.C. Jemilohun: overall oversight of study, conception and design of the study, analysis and interpretation of data, and manuscript write-up.

B.O. Oyelade: design of study, data collection and manuscript write -up.

S.O. Oiwoh: design of study, data analysis, manuscript write-up.

\section{References}

[1] Hou J., Liu Z., Gu F. (2005) Int J. Med. Sci., 2(1), 50-57.

[2] Lavanchy D. (2004) J. Viral. Hepat., 11(2), 97-107.

[3] Pennap G.R., Nwachukwu O., Ishaleku D., Ombugadu R.J. (2011) Res. J. of Med Sci., 5, 90-93.

[4] Kramvis A., Kew M.C. (2007) Hepatol. Res., 37(s1), S9-S19.

[5] Sirisena N.D., Njoku M.O., Idoko J.A., Isamade E., Barau C., Jelpe D., Zamani A., Otowo S. (2002) Niger. Postgrad. Med. J., 9(1), 7-10.

[6] Alao O.O., Okwori E.E., Egwu C., Audu F. (2009) Inter. J. Hematol., 5(2).

[7] Udeze A.O., Okonko O., Donbraye E., Sule W.F., Fadeyi A., Uche L.N. (2009) World Appl. Sci. J., 7(8), 1023-1028.

[8] Uneke C.J., Ogbu O., Inyama P.U., Anyanwu G.I., Njoku M.O., Idoko J.H. (2005) Mem. Inst. Oswaldo. Cruz., 100(1), 13-16.

[9] Jeremiah Z.A., Tony E.E.O. (2000) Nigeria Journal of Hepatitis, 9, 276-281.

[10]Bassey E.B., Moses A.E., Udo S.M., Umo A.N. (2009) Online J.
Health Allied Sci., 8, 1-5.

[11]Luka S.A., Ibrahim M.B., lliya M.B. (2008) Nig. J. Parasitol., 29, 38-41.

[12]Umolu P.I., Okoror L.E., Orhue P. (2005) Afr. Health Sci., 5(1), 55-58. 